PAULA, E.M.N. et al. Principais causas virais de abortamento em bovinos. PUBVET, Londrina, V. 8, N. 16, Ed. 265, Art. 1763, Agosto, 2014.

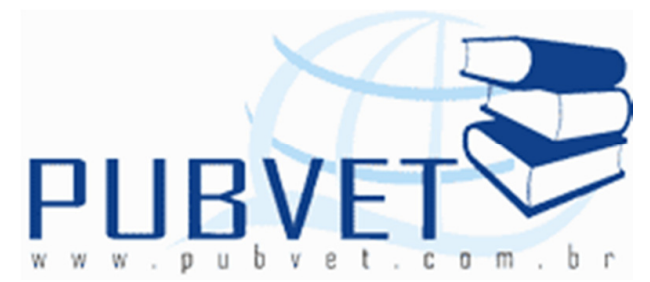

PUBVET, Publicações em Medicina Veterinária e Zootecnia.

\title{
Principais causas virais de abortamento em bovinos
}

\footnotetext{
Eric Mateus Nascimento de Paula ${ }^{1}$, Lilian Moreira Semer ${ }^{2}$, Carolina de Alvarenga $\mathrm{Cruz}^{3}$, Fernanda Cassioli de Moraes ${ }^{3}$, Luis Antonio Mathias ${ }^{4}$, Daniel Bartoli de Sousa ${ }^{5}$, Raphaella Barbosa Meirelles-Bartoli ${ }^{5}$
}

${ }^{1}$ Aluno do Curso de Medicina Veterinária da Universidade Federal de Goiás, Campus Jataí.

${ }^{2}$ Médica Veterinária Autônoma.

${ }^{3}$ Alunas do Curso de Pós-Graduação em Medicina Veterinária, Faculdade de Ciências Agrárias e Veterinárias, UNESP, Campus Jaboticabal.

${ }^{4}$ Docente do Curso de Medicina Veterinária da Faculdade de Ciências Agrárias e Veterinárias, UNESP, Campus Jaboticabal.

${ }^{5}$ Docentes do Curso de Medicina Veterinária da Universidade Federal de Goiás (UFG), Campus Jataí, Unidade Jatobá, Laboratório de Sanidade Animal.

\section{Resumo}

$\mathrm{O}$ ato da expulsão de um feto vivo ou morto do útero entre 5 semanas até aproximadamente 40 semanas de gestação é denominada de aborto, quando este é incapaz de exercer uma vida independente em um ambiente extrauterino. Somente $30 \%$ a $40 \%$ dos fetos bovinos abortados apresentam diagnóstico etiológico definido em virtude das múltiplas causas envolvidas. Entre essas causas temos a diarreia viral bovina e a rinotraqueíte infecciosa bovina. As perdas econômicas causadas por essas enfermidades são 
PAULA, E.M.N. et al. Principais causas virais de abortamento em bovinos. PUBVET, Londrina, V. 8, N. 16, Ed. 265, Art. 1763, Agosto, 2014.

representadas pela diminuição na reprodução, na infertilidade dos animais enfermos, nas mortes embrionárias com repetições de cios, nos abortos, nos nascimentos de bezerros com defeitos congênitos e com desenvolvimento retardado.

Palavras-chave: aborto, diarreia viral bovina, rinotraqueíte infecciosa bovina

\section{Viral main causes of abortion in cattle}

\section{Abstract}

The act of expelling a living or dead fetus from the uterus from 5 weeks to about 40 weeks of pregnancy is called abortion, when it is unable to exert an independent life in an extra-uterine environment. Only $30 \%$ to $40 \%$ of aborted fetuses have defined etiological diagnosis because of the many causes involved. Among these causes have bovine viral diarrhea and infectious bovine rhinotracheitis. The economic losses caused by these diseases are represented by the decrease in reproduction, infertility of sick animals, the embryonic deaths with repetitions of cycles, the abortions, the births of calves with congenital defects and delayed development.

Keywords: abortion, bovine viral diarrhea, infectious bovine rhinotracheitis

\section{INTRODUÇÃO}

Abortamento refere-se à expulsão de um feto vivo ou morto do útero entre 42 dias até aproximadamente 280 dias de gestação, quando este é incapaz de exercer uma vida independente em um ambiente extra-uterino (ANTONIASSI et al., 2007).

Apresenta diagnóstico etiológico definido em virtude das múltiplas causas envolvidas somente $30 \%$ a $40 \%$ dos fetos bovinos abortados. Além disso, a autólise devido morte fetal e posterior expulsão do feto, dificulta a identificação e isolamento do agente etiológico (ANTONIASSI et al., 2007).

Para o sucesso no diagnóstico, faz-se necessário alguns procedimentos que devem ser realizados de maneira criteriosa. Primeiramente, é muito 
PAULA, E.M.N. et al. Principais causas virais de abortamento em bovinos. PUBVET, Londrina, V. 8, N. 16, Ed. 265, Art. 1763, Agosto, 2014.

importante obter-se uma história adequada, que deve incluir questionamentos acerca do animal que abortou (como idade e histórico reprodutivo), e acerca do rebanho, como dieta, introdução de novos animais, vacinações, índices de prenhez e historia previa de abortamentos ou repetição do cio. A determinação precisa da ocorrência de abortamentos nos rebanhos é muito importante, pois índices de $1 \%$ a $2 \%$ são considerados normais para bovinos; de $3 \%$ representam um sinal de alerta e maiores que 3\% caracterizam um problema ambiental ou infeccioso que acomete o rebanho. Em segundo lugar, devem ser examinados o feto e a placenta. Avaliações sorológicas do feto e da mãe são realizadas como procedimentos complementares.

As ações de prevenção podem ser classificadas em dois níveis: controle e erradicação, de acordo com o objetivo em questão. O controle visa reduzir a frequência de ocorrência de uma doença já presente na população, enquanto que a erradicação busca eliminar totalmente a doença. Para tanto, medidas de defesa sanitária visando a biosseguridade são implantadas com a finalidade de se evitar que o agente etiológico infecte o animal suscetível, impedir a disseminação do agente e eliminar as condições predisponentes (FAVA et al., 2003).

Como causas virais temos, primeiramente, a diarreia viral bovina, em que a infecção ocorre na época da cobertura e interfere na concepção, seja se a mesma foi realizada por cobertura natural ou por inseminação artificial. Experimentalmente, a infusão intra-uterina do vírus no momento da inseminação impediu a fertilização do animal, sendo estes efeitos muito mais precoces sobre a reprodução do que os que ocorrem quando a infecção se dá por meio de outras fontes de contato. Vacas susceptíveis se são infectadas com o vírus, experimentalmente, durante os primeiros 100 dias de gestação podem abortar os produtos ou mesmo estes podem sofrer mumificação; se a infecção for realizada nos fetos ou nas vacas prenhes durante o $2^{\circ}$ e $03^{\circ}$ trimestre, não há aborto, mas os fetos infectados desenvolvem anticorpos neutralizantes (CORRÊA, CORRÊA, 1992). 
PAULA, E.M.N. et al. Principais causas virais de abortamento em bovinos. PUBVET, Londrina, V. 8, N. 16, Ed. 265, Art. 1763, Agosto, 2014.

Em segundo lugar, existe a rinotraqueíte infecciosa bovina, em que a forma genital, denominada comumente vulvovaginite pustular contagiosa, e no macho balanopostite pustular, surgem petéquias e pústulas na mucosa, às vezes confluentes, podendo estar cobertas por exsudato catarral abundante, ou por membrana difteróide; porém esta forma não é de transmissão venérea. Os abortos são atribuídos mais com a forma respiratória (CORRÊA, CORRÊA, 1992).

\section{DIARREIA VIRAL BOVINA (BVD)}

\subsection{DEFINIÇÃO}

A diarreia viral bovina é uma enfermidade infectocontagiosa dos bovinos com diferentes apresentações clínicas (GUIMARÃES et al., 2000).

A denominação "Diarreia Viral Bovina" abrange uma série de manifestações clínico-patológicas. Essa denominação deve-se ao fato do agente ter sido inicialmente identificado em casos de doenças gastroentérica em bovinos. Posteriormente, a infecção foi associada a uma ampla variedade de sinais clínicos, incluindo doença respiratória, digestiva, reprodutiva, hemorrágica, cutânea e imunossupressão. Embora possa estar associado a diferentes manifestações clínicas, a maioria das infecções de animais imunocompetentes pelo vírus da diarreia bovina (BVDV) parece cursar sem sintomatologia clínica aparente. Pelas consequências epidemiológicas e clínicopatológicas da infecção de fêmeas bovinas prenhes, o BVDV é considerado um vírus de importância predominantemente reprodutiva (FLORES, 2003).

A prevalência de animais soropositivos para o BVDV situa-se entre $60 \%$ a 90\% (QUINCOZES et al., 2007).

\subsection{HISTÓRICO}

Foi descrita pela primeira vez, em 1946, em Nova York, EUA. A doença foi sendo observada em outros países da América, como o Canadá, e vários países da Europa, quando em 1960, também nos EUA, isolaram uma amostra de vírus citopatogênica que permitiu cerificar sorologicamente sobre a 
PAULA, E.M.N. et al. Principais causas virais de abortamento em bovinos. PUBVET, Londrina, V. 8, N. 16, Ed. 265, Art. 1763, Agosto, 2014.

identidade ou grande similaridade dos agentes causadores das várias formas clínicas da doença (CORRÊA, CORRÊA, 1992).

O BVDV foi isolado pela primeira vez no Brasil por Vidor em 1974, a partir de amostras de soro bovino colhidas em abatedouros (GUIMARÃES et al., 2005).

No Brasil, a infecção e as enfermidades associadas ao BVDV são descritas desde os anos 60 (ANTONIASSI, 2007).

\subsection{ETIOLOGIA}

O BVDV pertence à família Flaviviridae, gênero Pestivirus, que ainda abriga dois outros vírus antigenicamente relacionados: o vírus da peste suína clássica (CSFV) e o border disease (doença da fronteira). Os pestivírus são vírus pequenos 40 a $60 \mathrm{~nm}$, envelopados e contém como genoma uma molécula de RNA. De acordo com a capacidade de produzir citopatologia em cultivos celulares, os isolados de BVD podem ser classificados em citopatogênico (CP) e não-citopatogênico (NCP). A grande maioria dos vírus de campo são NCP, enquanto amostras $\mathrm{CP}$ são isoladas quase que exclusivamente de animais acometidos da Doenças das Mucosas (DM) (FLORES, 2003).

Os isolados de campo apresentam uma grande variedade antigênica, sendo que dois grupos antigênicos principais já foram identificados: BVDV tipo I (BVDV-I) e BVDV tipo II (BVDV-II). Os vírus do genótipo BVDV-I representam a maioria dos vírus vacinais e das cepas de referência, enquanto os BVDV-II foram identificados recentemente em surtos de BVD aguda e doença hemorrágica na América do Norte. No entanto, atualmente, sabe-se que nem todos os BVDV-II são altamente patogênicos (FLORES, 2003).

O BVD é sensível a solventes lipídicos como éter e clorofórmio e é inativado por tratamento com tripsina. $\mathrm{O}$ vírus é mais estável na faixa de $\mathrm{pH}$ 5,7 a 9,3 com estabilidade máxima em $\mathrm{pH}$ de 7,4. É facilmente mantido em estado liofilizado ou congelado $\left(-70,0^{\circ} \mathrm{C}\right)$ por vários anos (GONDIM, 2006). 
PAULA, E.M.N. et al. Principais causas virais de abortamento em bovinos. PUBVET, Londrina, V. 8, N. 16, Ed. 265, Art. 1763, Agosto, 2014.

\subsection{EPIDEMIOLOGIA}

\subsubsection{Distribuição Geográfica}

É um agente infeccioso de distribuição mundial, cuja disseminação na população bovina do país foi comprovada por meio de isolamentos e inquéritos sorológicos (QUINCOZES et al., 2007).

Como pode ser comprovado em extensas investigações sorológicas, o grau de morbidade em bovinos nos diversos países é de 20-95\% (BEER, 1999).

\subsubsection{Cadeia Epidemiológica}

\subsubsection{Fonte de infecção}

Os reservatórios são os próprios bovinos, quer como doentes crônicos quer como portadores (CORRÊA, CORRÊA, 1992).

Como o vírus pode persistir em presença de anticorpos neutralizantes nos linfócitos e macrófagos e ser capaz de multiplicar-se, os animais com reação sérica positiva devem ser considerados como eliminadores potenciais do vírus (LIEBERMANN, 1999).

A infecção de fêmeas entre os dias 40 e 120 de gestação frequentemente resulta em infecção fetal com o subsequente nascimento de bezerros imunotolerantes, persistentemente infectados (PI), geralmente soro-negativo, podendo ser clinicamente normais, excreta o vírus continuamente em grande quantidade em secreções. Por isso, é considerado ponto-chave na epidemiologia da infeç̧ão (ANTONIASSI, 2007; SIEDLER, 2008). Somente o biótipo NCP estabelece infecção persistente e é responsável pela circulação permanente do BVDV na população bovina (SIEDLER, 2008).

\subsubsection{Vias de eliminação}

Os animais infectados eliminam o vírus pelas mucosas da região da cabeça (secreções nasais, oculares e salivar), assim como pelas fezes contaminando a água e alimento (BEER, 1999). 
PAULA, E.M.N. et al. Principais causas virais de abortamento em bovinos. PUBVET, Londrina, V. 8, N. 16, Ed. 265, Art. 1763, Agosto, 2014.

Além disso o BVDV também pode ser eliminado urina, sêmen, embrião, placenta, sangue e se caracteriza por induzir altas taxas de soropositividade nos rebanhos expostos (QUINCOZES et al., 2007.

\subsubsection{Meios de transmissão}

Através do PI, o vírus se mantém endêmico em um rebanho, podendo ser transmitido através de contato direto ou indireto (SIEDLER, 2008).

A transmissão da enfermidade também se dá por via transplacentária, por meio de vacinas vivas modificadas, ou vacinas contra outras enfermidades mas que estão contaminadas com o BVDV, ou através do soro fetal (em certos procedimentos de alta tecnologia) (CORRÊA, CORRÊA, 1992).

\subsubsection{Porta de entrada}

O vírus penetra no organismo pelas vias digestivas, aerógena ou através das mucosas. A infecção evolui na população regularmente com sinais suaves ou de forma subclínica. Mas também são registradas formas subagudas e agudas. A diarreia viral/doença das mucosas podem apresentar-se em um rebanho de maneira explosiva, apesar de, também, pode ter um período de incubação prolongado (LIEBERMANN, 1999).

\subsubsection{Hospedeiros susceptíveis}

Podem ser acometidos bovinos de todas as idades, entretanto resulta mais afetado o bovino de idade compreendida entre 3 e 18 meses (BEER, 1999).

A infecção natural ocorre em bovinos, e também em ovinos, suínos, caprinos, ruminantes de vida livre ou de cativeiro. São também susceptíveis coelhos, búfalos, Ihamas e alpacas. Essas espécies são consideradas fontes potenciais de infecção, mas seu exato papel na epidemiologia ainda deve ser esclarecido. As raças de maiores rendimentos parecem estar particularmente predispostas a sofrer contágio (GONDIM, 2006). 
PAULA, E.M.N. et al. Principais causas virais de abortamento em bovinos. PUBVET, Londrina, V. 8, N. 16, Ed. 265, Art. 1763, Agosto, 2014.

As consequências clinico-patológicas da infecção pelo BVDV variam principalmente de acordo com a idade e/ou categoria de animal que o vírus infecta (FLORES, 2003).

\subsection{PATOGENIA}

A porta de entrada do vírus no organismo não interfere na evolução da doença. Entre $1^{\circ}$ e $4^{\circ}$ dias após infecção inicia-se a fase virêmica, na qual o vírus é evidente no plasma, unindo a eritrócitos e leucócitos. O vírus dissemina-se pela corrente sanguínea e linfática, atingindo quase todos os órgãos. Concentrações de vírus particularmente elevadas aparecem nas membranas da cabeça, intestino, vias respiratórias, baço, gânglios linfáticos, pâncreas, adrenais e glândulas salivares. Entre o 90 e $16^{\circ}$ dias pós-infecção, surgem anticorpos neutralizantes, que eliminam do sangue o vírus livre. Entretanto, apesar da presença de anticorpos neutralizantes, o vírus pode persistir nos linfócitos e macrófagos altera o metabolismo celular de tal forma, que as células infectadas já não são capazes de multiplicar-se, sintetizar anticorpos nem produzir interferon, o que vem a facilitar a multiplicação de outros vírus e micro-organismos (LIEBERMANN, 1999).

\subsection{SINAIS CLÍNICOS}

O período de incubação é de 2 a 14 dias. As primeiras manifestações da doença consistem na elevação, geralmente bifásica, da temperatura e leucopenia (BEER, 1999).

A infecção pelo BVDV pode resultar em uma grande variabilidade de sinais clínicos, relacionados com doença reprodutiva, respiratória ou digestiva. A sua capacidade de cruzar a barreira placentária durante a gestação pode causar infertilidade temporária, queda nas taxas de concepção, morte embrionária e abortamento, mumificação fetal e natimortalidade (QUINCOZES et al., 2007). 
PAULA, E.M.N. et al. Principais causas virais de abortamento em bovinos. PUBVET, Londrina, V. 8, N. 16, Ed. 265, Art. 1763, Agosto, 2014.

\subsection{DIAGNÓSTICO}

O diagnóstico de rotina das infecções por BVDV é comumente feito por meio de sinais clínicos (perdas embrionárias, abortamento, malformações fetais, nascimento de animais fracos, morte perinatal). Além disso, casos de doença entérica e/ou respiratória com componentes hemorrágicos como: melena, petéquias em mucosas, serosas, presença de lesões macro e microscópicas compatíveis e pelo isolamento viral em fluidos corporais, excreções ou tecidos infectados (FLORES, 2003; ANDRADE et al., 2005). Métodos alternativos, como imunoistoquímica, tem sido desenvolvidos com intuito de aumentar a rapidez do diagnóstico da BVD. Mais recentemente, foi utilizada como método de triagem em bezerros recém-nascidos a partir de biópsias de pele para a detecção de PI, podendo ser empregada na rotina por ser de boa acurácia e economicamente viável (ANDRADE et al., 2005).

Embora a técnica padrão para o diagnóstico sorológico da infecção pelo BVDV seja a soro-neutralização (SN), outras técnicas têm sido avaliadas e utilizadas no país. Desenvolveram a padronização de um teste ELISA para detecção de anticorpos contra o BVDV. O teste utiliza antígenos recombinantes produzidos e demonstrou sensibilidade de $97,6 \%$ e especificidade de $99,4 \%$ quando comparado com a SN e pode ser realizado facilmente em um grande número de amostras. Animais infectados de forma aguda, soroconvertem 14 a 20 dias após a infecção inicial. Nestes animais, a sorologia pareada, ou seja, a coleta de soro no momento da suspeita clínica e uma segunda coleta 15 a 20 dias após, pode indicar a infecção pelo vírus. A elevação dos títulos de anticorpos em pelo menos quatros vezes indica que o animal estava infectado pelo vírus no momento da primeira coleta. A sorologia com amostras únicas tem valor diagnóstico limitado nas infecções pelos BVDV, pois indica apenas que houve exposição prévia. Exames sorológicos de rebanhos, devido a prática de vacinação, tem valor epidemiológico limitado, e servem unicamente para verificar o status sorológico e a possível presença do vírus no rebanho. A detecção e quantificação de anticorpos em amostras de leite coletadas nos locais de coleta ou na indústria têm sido utilizadas para a identificação de 
PAULA, E.M.N. et al. Principais causas virais de abortamento em bovinos. PUBVET, Londrina, V. 8, N. 16, Ed. 265, Art. 1763, Agosto, 2014.

rebanhos com atividade viral (FLORES, 2003; FLORES et al., 2005). O teste padrão de diagnóstico é o isolamento do agente em cultivos celulares seguido por identificação por imunofluorescência (IFA) e/ou imunoperoxidase (IPX). células de origem bovina são bastante sensíveis ao vírus. Isolamento do vírus ou detecção de RNA viral por PCR no leite tem sido utilizados para identificar rebanhos leiteiros infectados (FLORES, 2003).

Os materiais de eleição para o diagnóstico da infecção pelo vírus da BVD devem ser sangue com anticoagulante (para deteç̧ão de animais PI ou de animais na infecção aguda), soro (preferencialmente pareado), órgãos (baço, timo, intestino e linfonodos), fetos e envoltórios fetais (placenta e placentomas), além de órgãos ou tecidos com lesões macroscópicas. Para o isolamento viral, os órgãos ou tecidos com lesões devem ser conservados em formalina a $10 \%$. No caso de animais doentes suspeitos, o sangue com anticoagulante é o material preferencial (FLORES, 2003).

O sangue de animais infectados de forma aguda ou persistente é muito rico em vírus. Para este fim, o material precisa ser coletado de forma asséptica, pois a contaminação bacteriana pode inviabilizar o isolamento. Devido a possibilidade da presença de cepas NCP, todos os materiais que forem negativos para efeito citopático nos cultivos celulares, precisam ser testados por métodos que demonstrem a presença de antígenos virais antes de serem diagnosticados como negativos (FLORES, 2003).

\subsection{ACHADOS ANATOMOPATOLÓGICOS}

O quadro anatomopatológico varia segundo as distintas formas clínicas da doença. Destacam erosões, úlceras, hemorragias, edemas e focos inflamatórios na mucosa de todo o tubo digestivo (BEER, 1999).

\subsection{TRATAMENTO}

Não existe tratamento específico para esta doença (GONDIM, 2006) e o tratamento sintomático não costuma ter êxito (BEER, 1999). 
PAULA, E.M.N. et al. Principais causas virais de abortamento em bovinos. PUBVET, Londrina, V. 8, N. 16, Ed. 265, Art. 1763, Agosto, 2014.

\subsection{PROGNÓSTICO}

É desfavorável, pois a evolução é rápida com alta letalidade (CORRÊA, CORRÊA 1992), ainda mais quando existem lesões das mucosas e desidratação (BEER, 1999).

\subsection{MEDIDAS DE CONTROLE E PREVENÇÃo}

A escolha das estratégias mais adequadas para a profilaxia e controle da infecção pelo BVDV depende das condições específicas de cada rebanho. Em geral, essas estratégias consistem na prevenção da entrada de animais PI e/ou remoção destes de uma propriedade, além da utilização de vacinas. O principal objetivo da vacinação deve ser prevenir a infecção fetal e, assim, evitar a contínua geração de animais PI. Essas vacinas contêm cepas inativadas ou atenuadas do BVDV-I e/ou BVDV-II. No Brasil, somente são comercializadas vacinas inativadas, contendo cepas americanas do BVDV. Além disso, a maioria destas vacinas contém apenas amostras do genótipo 1. Estudos recentes demonstraram que essas vacinas induzem níveis baixos de anticorpos neutralizantes em ovinos e bovinos, principalmente contra amostras brasileiras de BVDV II. Nesse sentido, é evidente a necessidade da elaboração de vacinas que contenham amostras representativas dos isolados de campo brasileiros de ambos os genótipos e que induzam níveis adequados de anticorpos com amplo espectro antigênico (LIMA et al., 2003).

\section{RINOTRAQUEÍTE INFECCIOSA BOVINA (IBR) \\ 3.1 DEFINIÇÃO}

O Herpesvírus Bovino tipo-1 (BHV-1) é considerado um dos principais patógenos de bovinos, sendo responsável por grandes prejuízos econômicos na exploração pecuária. Clinicamente, as infecções pelo BVH-1 manifestam-se sob formas distintas, entre as quais se destacam a respiratória (Rinotraqueíte Infecciosa Bovina - IBR), genital (Vulvovaginite/Balanopostite Pustular Infecciosa - IPV/IPB), sistêmica, nervosa e reprodutiva (MÉDICI, ALFIERI, ALFIERI, 2000). 
PAULA, E.M.N. et al. Principais causas virais de abortamento em bovinos. PUBVET, Londrina, V. 8, N. 16, Ed. 265, Art. 1763, Agosto, 2014.

\subsection{HISTÓRICO}

O BHV-1, agente responsável por causar a IBR, foi identificado pela primeira vez nos EUA, em 1957. Abortos por BHV-1 geralmente ocorrem em gestações com mais de 6 meses (ANTONIASSI, 2007).

Normalmente a doença não costuma ser fatal, e as mortes, em grande parte, devem-se aos abortamentos e à redução da condição corporal e produção de leite. Nos rebanhos leiteiros, os prejuízos podem situar-se entre 25 e 50 dólares por cabeça (CAVALCANTE, 2000).

\subsection{ETIOLOGIA}

O BHV-1 pode ser classificado em sub-tipos, sendo o BHV-1.1 (IBR-like) relacionado com problemas respiratórios, reprodutivos e casos de conjuntivite. O BHV-1.2A e BHV-1.2B (IPV-like) são mais frequentes em infecções relacionadas com o trato genital. O BHV-1.3A e o BHV-1.3B, atualmente reclassificados como BHV-5, determina sintomatologia nervosa em bezerros e animais adultos sendo responsável pelo quadro clínico de meningoencefalite (TAKIUCHI, ALFIERI, ALFIERI, 2001).

O BHV-1 encontra-se amplamente disseminado. A partícula viral tem entra 70 a $110 \mathrm{~nm}$ de diâmetro e é constituída por um capsídeo icosaédrico, envelope glicoproteico e genoma DNA linear de fita dupla (TAKIUCHI, ALFIERI, ALFIERI, 2001).

O vírus da IBR e IPV/IPB são membros da família Herpesviridae, subfamília Alfaherpesvirinae (ROEHE et al., 1997).

\subsection{EPIDEMIOLOGIA}

\subsubsection{Distribuição Geográfica}

A IBR é uma das principais enfermidades infecto-contagiosas de bovinos e possui distribuição mundial (WINKELMANN et al., 2007).

O BHV-1 está presente em forma enzoótica no Brasil há vários anos, com evidências sorológicas da infecção, virtualmente em todos os locais onde foram pesquisadas (ROEHE et al., 1997). 
PAULA, E.M.N. et al. Principais causas virais de abortamento em bovinos. PUBVET, Londrina, V. 8, N. 16, Ed. 265, Art. 1763, Agosto, 2014.

A IBR apresentou no Estado do Pará frequência total de 50,8\% de animais soropositivos ao BHV-1, encontrada em reprodutores de corte, foi significativamente superior à detectada em animais de aptidão leiteira 41,9\% (MÉDICI, ALFIERI, ALFIERI, 2000).

\subsubsection{Cadeia Epidemiológica}

\subsubsection{Fonte de infecção}

O reservatório são os próprios bovinos portadores, que apesar da cura clínica, o vírus pode continuar a replicar-se de tal forma que até 11 meses após-infecção ainda se isola o vírus (CORRÊA, CORRÊA, 1992).

Nas criações de bovinos livres da doença o vírus é introduzido, na maioria dos casos, por animais doentes ou infectados de forma latente, neste último caso, tanto mais facilmente porque, ao não apresentar sinais, não despertam nenhuma suspeita do possível contágio (BEER, 1999).

\subsubsection{Vias de eliminação}

Tanto na infecção aguda quanto na reativação da latência há excreção viral em secreções genitais e nasais. Contudo, a massa viral e o tempo em que é eliminada são maiores na primeira infecção quando comparados à segunda (VOGEL et al, 2003 e 2004). Além das vias já citadas, estudos sugerem que esses micro-organismos possam ser eliminados naturalmente pelo leite (PROBST et al., 1985), sêmen (geralmente contaminado durante a ejaculação por contato com o vírus presente na mucosa prepucial), lavado uterino, vísceras de animais necropsiados, vísceras de fetos abortados e placenta (DEL FAVA et al., 2003).

\subsubsection{Meios de transmissão}

A via de transmissão direta horizontal é a mais importante e ocorre através do contato direto entre os animais e também pela cópula, porém o embrião e feto podem infectar-se pela via vertical (transplacentária). A transmissão indireta ocorre principalmente por aerossóis, fômites, tendo a 
PAULA, E.M.N. et al. Principais causas virais de abortamento em bovinos. PUBVET, Londrina, V. 8, N. 16, Ed. 265, Art. 1763, Agosto, 2014.

inseminação artificial importante papel na entrada da doença em rebanhos que nunca tiveram contato com o vírus (DEL FAVA et al., 2003).

Um vírus adaptado aos órgãos genitais adapta-se aos órgãos respiratórios, quando a possibilidade de transmissão do vírus da mucosa vaginal à mucosa é feita rapidamente (BARTHA, 1999).

\subsubsection{Porta de entrada}

A infecção pode ser adquirida por via respiratória, digestiva e conjuntival (CORRÊA, CORRÊA, 1992).

A infecção é mantida, com frequência, na forma latente. Por outro lado, quando um vírus adaptado penetra nos órgãos do aparelho respiratório de um animal, a afecção apresenta-se na forma respiratória (RIB). Em bezerros de engorda e vacas aparece uma inflamação das vias respiratórias superiores ou desenvolve-se um estado febril sem sinais característicos de afecção respiratória. Os bezerros sofrem, em geral, esta segunda forma clínica. O vírus experimenta um considerável aumento da sua virulência ao passar rapidamente por distintos animais do rebanho (BARTHA, 1999).

Em alguns casos a infecção produz abortamentos. A doença nestes animais pode evoluir de forma tão discreta que passa despercebida. O vírus pode também não afetar o feto. Em certo número de vacas, entretanto, o vírus pode chegar ao feto e multiplicar-se em seus tecidos, produzindo, desta forma, graves lesões que conduzem ao abortamento (BARTHA, 1999).

\subsubsection{Hospedeiros susceptíveis}

São receptíveis os bovinos de todas as idades (BEER, 1999), de todas as raças e de ambos os sexos (CORRÊA, CORRÊA, 1992). São bem menos receptíveis outras espécies de ruminantes (cabra, cervo) (BEER, 1999).

\subsection{PATOGENIA}

A habilidade do BHV-1 persistir no hospedeiro e ser submetido a episódios de reativação após infecção genital tem sido bem demonstrada e foi inicialmente 
PAULA, E.M.N. et al. Principais causas virais de abortamento em bovinos. PUBVET, Londrina, V. 8, N. 16, Ed. 265, Art. 1763, Agosto, 2014.

atribuída a uma imunidade de curta duração. Estudos clássicos demonstraram que o vírus persiste no rebanho por meio de episódios periódicos de reativação da infecção latente. Após a infecção ou inoculação do BHV-1.2 no trato genital em fêmeas, o vírus replica na mucosa local e estabelece infecção latente nos gânglios sacrais. Reativação esporádica da infecção latente e consequente reexcreção viral podem ocorrer de forma natural ou serem induzidas pela administração de corticosteroides. A reativação da infecção latente pode ser acompanhada de um período de excreção viral sem necessariamente estar acompanhada de sinais clínicos. Assim, a infecção latente e posterior reativação explicam a persistência do vírus e o aparecimento de novos casos clínicos no rebanho ao longo do tempo. A infecção latente pelo BHV-1.2 em fêmeas tem sido pouco estudada e vários aspectos da patogenia permanecem não esclarecidos (HENZEL et al., 2008).

\subsection{SINAIS CLÍNICOS}

A infecção determinada pelo BHV-1 afeta principalmente os tratos respiratórios e genital dos bovinos e pode ser subdividida em duas entidades clínicas denominadas IBR e IPV/IPB (TAKIUCHI, ALFIERI, ALFIERI, 2001).

A forma respiratória caracteriza-se por aumento da temperatura corporal, hiperemia das mucosas, rinite, dispneia, corrimento nasal seroso, lesões erosivas na mucosa nasal e, ocasionalmente, pneumonia. A taxa de mortalidade é baixa, mas podem ocorrer complicações em decorrência de infecções bacterianas secundárias ou de outras infecções virais superpostas (TAKIUCHI, ALFIERI, ALFIERI, 2001).

Em fêmeas, a forma genital manifesta-se clinicamente pelo aparecimento de pequenas vesículas de 1 a $2 \mathrm{~mm}$ de diâmetro que evoluem para pústulas e erosões localizadas na vulva e vagina. O epitélio vulvar apresenta-se edemaciado, hiperêmico e com secreção que pode tornar-se mucopurulenta devido à contaminação bacteriana secundária. Em touros, lesões similares são encontradas no prepúcio e pênis (TAKIUCHI, ALFIERI, ALFIERI, 2001). 
PAULA, E.M.N. et al. Principais causas virais de abortamento em bovinos. PUBVET, Londrina, V. 8, N. 16, Ed. 265, Art. 1763, Agosto, 2014.

Entretanto, IBR e IPV não são as únicas formas de manifestação clínica das infecções pelo BHV-1. Tanto em rebanhos de corte quando de leite também podem ocorrer quadros clínicos de conjuntivite, enterite, encefalite e distúrbios reprodutivos. Estes são caracterizados por mortalidade embrionária precoce e/ou tardia, com repetições de cios a intervalos regulares e/ou irregulares; mortalidade fetal com aborto; natimortos; mortalidade neonatal e infertilidade (TAKIUCHI, ALFIERI, ALFIERI, 2001).

\subsection{DIAGNÓSTICO}

Além das sintomatologias clínicas encontradas no rebanho, o diagnóstico mais eficiente é o laboratorial. A presença de focos microscópicos de necrose com inclusões intracelulares eosinofílicas e a ausência de inflamação nos tecidos fetais, especialmente fígado, pulmões, timo, glândula adrenal, sugerem o abortamento por herpesvírus. A confirmação do diagnóstico é feita pelo isolamento do vírus da placenta ou pulmão fetal, ou pela demonstração de antígeno viral no rim fetal ou em outro tecido, por meio de testes de anticorpos fluorescentes (AF) (CAVALCANTE, 2000).

\subsection{TRATAMENTO}

$\mathrm{Na}$ vigência do surto, não havendo agente terapêutico específico, procurar deixar os animais em descanso (CORRÊA, CORRÊA, 1992).

É improvável que os antibióticos tenham alguma ação sobre o vírus, mas devem ser administradas os de largo espectro, com a finalidade de se evitar mortes originadas por invasores bacterianos secundários (CAVALCANTE, 2000).

\subsection{PROGNÓSTICO}

O prognóstico é bom devido à baixa mortalidade nos casos respiratórios, e nula nos casos genitais (CORRÊA, CORRÊA, 1992). 
PAULA, E.M.N. et al. Principais causas virais de abortamento em bovinos. PUBVET, Londrina, V. 8, N. 16, Ed. 265, Art. 1763, Agosto, 2014.

\subsection{MEDIDAS DE CONTROLE E PREVENÇÃO}

As vacinas previnem o desenvolvimento de sinais clínicos e reduzem a eliminação de partículas virais, no entanto, não impedem a infecção viral e latência (DEL FAVA et al., 2003).

Países europeus com baixa prevalência do HVB-1 nunca permitiram o uso de vacinas e erradicaram a enfermidade utilizando sorodiagnóstico e eliminação dos animais reagentes. Quando a prevalência do HVB-1 é elevada, a erradicação torna-se onerosa pelo custo dos descartes, sendo mais viável neste caso, a vacina com marcador genético que permite a diferenciação entre animais infectados e vacinados utilizando um teste ELISA, porém a comercialização desta vacina não está autorizada no Brasil (DEL FAVA et al., 2003).

Em condições experimentais, a erradicação do HVB-1 foi realizada com sucesso em plantéis bovinos de carne sob manejo extensivo e confinamento, onde as condutas sanitárias adotadas foram sorodiagnóstico periódico, isolamento e descarte dos animais sororeagentes e reposição das matrizes infectadas com animais não infectados (DEL FAVA et al., 2003).

\section{IMPACTO ECONÔMICO}

Tanto as fêmeas quanto os machos necessitam de um controle de doenças que causam impacto econômico no sistema de produção, durante a fase reprodutiva (ANDREOTTI, 1997).

A diarreia viral bovina (BVD) acarreta perdas econômicas por aborto, infertilidade, defeitos congênitos, natimortos e atraso no desenvolvimento dos animais infectados. Nos prejuízos econômicos provocados pelo insucesso de cobertura, retorno ao cio ou falha na parição, indicados pela taxa de prenhez e natalidade, as doenças da reprodução possuem um peso importante (ANDREOTTI, 1997). Apesar dos esforços realizados para o controle e erradicação do BVDV nos Estados Unidos e Europa, o impacto econômico da infecção em rebanhos de corte e leite ainda é significativo. Estudos realizados para estimar o impacto econômico da infecção pelo BVDV em rebanhos 
PAULA, E.M.N. et al. Principais causas virais de abortamento em bovinos. PUBVET, Londrina, V. 8, N. 16, Ed. 265, Art. 1763, Agosto, 2014.

leiteiros indicam que as perdas situam-se entre 10 e 40 dólares por bezerro nascido (LIMA et al., 2003).

O principal impacto econômico da IBR é observado pelo retardo de crescimento de animais jovens, menor produção leiteira, morte embrionária e fetal, reduzida eficiência reprodutiva de matrizes e touros (LEMAIRE, PASTORET, THIRY, 1994).

\section{DIAGNÓSTICO DIFERENCIAL}

O sucesso no diagnóstico de abortamento depende de alguns fatores. $O$ envio de fetos abortados juntamente com a placenta, a realização de necropsia, incluindo coleta adequada de materiais e a execução de exames histopatológicos, microbiológicos, imunoistoquímicos, sorológicos e micológicos compõem o conjunto de métodos necessários para a obtenção do diagnóstico de causas de aborto (ANTONIASSI et al., 2007).

A diarreia viral bovina e a rinotraqueite são diagnóstico diferencial uma da outra. Além de que no caso da BVD, ela ainda deve ser diferenciada da febre catarral maligna, de estomatite papulosa, de febre aftosa, das diarreias de inverno de etiologia desconhecida, das infecções por adenovírus e, especialmente, de peste bovina (BEER, 1999).

\section{CONCLUSÃo}

Se tratando destas causas virais de abortamento, com alto grau de importância tanto na pecuária de leite como na de corte, sabe-se que muitos criadores, ainda hoje, desconhecem estas patologias de caráter viral, ou ainda, as subestimam por falta de conhecimento a respeito do impacto econômico negativo que as mesmas geram após sua instalação, ou ainda, por acreditar ser oneroso de mais, casos de produtores já terem certo conhecimento e não investirem em profilaxia, controle e prevenção, expondo assim, seu rebanho e de propriedades vizinhas, apesar de que o uso do manejo reprodutivo e sanitário adequados tornaram-se uma das formas de profilaxia e prevenção de abortamento em bovinos por causa infecciosa da rotina da propriedade. 
PAULA, E.M.N. et al. Principais causas virais de abortamento em bovinos. PUBVET, Londrina, V. 8, N. 16, Ed. 265, Art. 1763, Agosto, 2014.

Fazem-se necessários ainda muitos estudos que busquem por incrementar as formas diagnósticas as tornando mais precisas, práticas, mais acessíveis economicamente e que demandem menor tempo para obtenção do resultado. Da mesma forma, estudos para tratamentos mais eficazes.

\section{REFERÊNCIAS BIBLIOGRÁFICAS}

ANDRADE, G. I.; SERRA, C. V.; BARBOSA-STANCIOLI, E. F.; SERAKIDES, R.; LOBATO, Z. I. P. Padronização da técnica de imunoistoquímica para diagnostico etiológico de rotina da diarreia bovina a virus. Arq. Bras. Med. Vet. Zootec. v.57, n.5, p.710-714, 2005.

ANDREOTTI, R. Gado de Corte Divulga: Cuidados com as doenças da reprodução na estação de monta. Embrapa, Mato Grosso, Campo Grande, jan. 1997.

ANTONIASSI, N. A. B.; SANTOS, A. S.; OlIVEIRA, E. C.; PESCADOR, C. A.; DRIEMEIER, D. Diagnóstico das causas infecciosas de aborto em bovinos - Palestra. Biológico, São Paulo, v. 69, n. 2, p. 69-72, jul./dez., 2007.

BARTHA, A. IBR In: BEER, J. Doenças infecciosas em Animais Domésticos. São Paulo: Livraria Roca Ltda, 1999. p.280-288.

BEER. J. Doenças Infecciosas Em Animais Domésticos. Ed. ROCA. Vol2. 2a Edição. São Paulo. 1999.

CAVALCANTE, F. A. Instruções técnicas - Rinotraqueite infecciosa bovina (nariz vermelho), diagnostico e controle.Embrapa, n.28, p.1-2, abril, 2000.

CORRÊA. W. M; CORÊA. C. N. M. Enfermidade Infecciosas dos mamíferos domésticos. Ed. MEDSI. 2a Edição. São Paulo, 1992.

DEL FAVA, C.; ARCARO, J.R.P.; POZZI, C.R.; ARCARO JÚNIOR, I.; FAGUNDES, H.; PITUCO, E. M.; DE STEFANO, E.; OKUDA, L.H.; VASCONCELLOS, S.A. Manejo reprodutivo sanitário para o controle de doenças da reprodução em um sistema leiteiro de produção semi-intensivo. Arq. Inst. Biol., São Paulo, v. 70, n. 1, p. 25-33, jan./mar., 2003.

FLORES, E. F. Divulgação técnica - Vírus da diarreia viral bovina (BVDV).Biológico, São Paulo, v.65, n.1/2, p.3-9, jan./dez., 2003.

FLORES, E. F.; WeIBLen, R; VOGEL, F. S. F.; ROEHE, P. M.; ALFIERI, A. A.; PITUCO, E. M. A infecção pelo virus da Diarreia Viral Bovina (BVDV) no Brasil - histórico, situação atual e perspectivas. Pesq. Vet. Bras. v.25, n.3, p. 125-134, jul./set. 2005.

GONDIN, A. C. L. O. Diarreia viral bovina. Monografia do curso de pós-graduação "LatoSensu" em Produção e Reprodução de Bovinos apresentado à Universidade Castelo Branco como requisite parcial para a obtenção de título de Especialista em Produção e Reprodução de Bovinos. Brasília, set. 2006.

GuimarÃES, P. L. S. N.; CHAVES, N. S. T.; SILVA, L. A. F.; ACYPRESTE, C. S. Frequência de anticorpos contra o virus da diarreia bovina em bovinos do encontro de Goiânia, em regime de criação semi-extensivo. Ciência Animal Brasileira v. 1, n. 2, p. 137-142, jul./dez. 2000. 
HENZEL, A.; DIEL, D. G.; ARENHART, S.; VOGEL, F. S. F; WEIBLEN, R.; FLORES, E. F. Aspectos virológicos e clinico-patologicos da infecção genital aguda e latente pelo herpesvirus 1.2 embezerras infectadas experimentalmente. Pesq. Vet. Bras.v.28, n.3. Rio de Janeiro. mar. 2008.

LEMAIRE, P.; PASTORET, P.; THIRY, E. Le contrôle de infection par lê virus de la rhinotraquéite infectiouse bovine. An. Méd. Vet. v.138, p. 167-180, 1994.

LIEBARMANN, H. BVD In: BEER, J. Doenças Infecciosas em Animais Domésticos. São Paulo: Livraria Roca Ltda, 1999. p. 89-93.

LIMA, M.; FLORES, E. F.; WEIBLEN, R.; VOGEL, F. S. F.; ARENHART, S. Caracterização de amostras atenuadas do virus da diarreia viral bovina (BVDV) tipos 1 e 2 para uso em vacinas. Pes. Bras. Vet. Rio de Janeiro , v. 24, n. 1, Mar. 2004

MÉDICI, K. C.; ALFIERI, A. A. ; ALFIERI, A. F. Prevalência de anticorpos neutralizantes contra o herpesvírus bovino tipo 1 , decorrente de infecção natural, em rebanhos com distúrbios reprodutivos. Ciência Rural, Santa Maria, v.30, n.2, p.347-250, 2000.

PROBST, U.; WYLER, R.; KIHM, U.; ACKERMANN, M.; BRUCKNER, L.; MULLER, H. K.; EHRENSPERGER, F. Excretion of IBR virus, especially in Milk, in experimentally infected cows. Schweizer Archiv fur Tiérheikunde, v. 127, p.723-733, 1985.

QUINCOZES, C. G.; FISCHER, G.; HUBNER, S. O.; VARGAS, G. D'AVILA.; VIDOR, T.; BROD, C. S. Prevalência e fatores associados à infecção pelo virus da diarreia viral bovina na região Sul do Rio Grande do Sul. Ciências Agrárias, Londrina, v.28, n.2, p.269-276, abr./jun. 2007.

ROEHE, P. M.; SILVA, T. C.; NARDI, N. B.; OLIVEIRA, L. G.; ROSA, J. C. A. Diferenciação entre os virus da rinotraqueite infecciosa bovina (BHV-1) e herpesvirus da encefalite bovina (BHV-5) com anticorpos monoclonais. Pesq. Vet. Bras. v.17, n.1, p.41-44, jan./mar. 1997.

SIEDLER, B. S.;FINGER, P.F.; MUNHOZ, L.S.; FERREIRA, L.N.; VILELA, C.O.; CAETANO, C.F.; VARGAS, G.D.; HÜBNER, S.O.; VIDOR, T.; FISCHER, G. Prevalência de infecções por herpesvírus bovino tipo 1 e 5 (BoHV-1 E 5) e pelo virus da diarreia viral bovina (BVDV) em rebanhos no Estado do Rio Grande do Sul no periodo de janeiro de 2003 a junho de 2008. Laboratório de Imunologia e Virologia, Faculdade de Veterinária, UFPel, 2008.

TAKIUCHI, E.; ALFIERI, A. F.; ALFIERI, A. A. Herpesvírus bovino tipo 1: Tópicos sobre a infecção e métodos de diagnostico. Semina: Ci. Agrárias, Londrina, v.22, n.2, p. 203-209, jul./dez. 2001.

VOGEL, F. S. F.; CARON, L.; FLORES, E. F.; WEIBLEN, R.; WINKELLMANN, E. R.; MAYER, S. V.; BASTOS, G. Distribution of bovine herpesvirus type5 (BHV-5) DNA in the central nervous system oflatently, experimentally infected calves. Journal of Clinical Microbiology, v. 41, p. 4512-4520, 2003.

VOGEL, F. S. F.; LIMA, M.; FLORES, E. F.; WEIBLEN, R.; WINKELLMANN, E. R.; MAYER, S. V.; MAZZUTTI, K. C.; ARENHART, S. Replicação e excreção viral durante a infecção aguda e após a reativação da latência induzida por dexametasona em bezerros inoculados com os herpesvírus bovinos tipo 1 (BHV-1) e 5 (BHV-5). Ciência Rural, Santa Maria, v. 34, p. 1619-1621, 2004.

WINKELMANN, E. R.; SILVA, L. F.; MAYER, S. V.; MAZZUTTI, K. C.; WEIBLEN, R.; FLORES, E. F. Produção e caracterização de anticorpos monoclonais contra uma cepa de herpevirus bovino tipo 1 defectiva na glicoproteína c (gC). Ciência Rural, Santa Maria, v.37, n.4, p.1066-1072, jul-ago. 2007. 